\title{
Inhibition of Hydrogen Peroxide, Nitric Oxide and TNF- $\alpha$ Production in Peritoneal Macrophages by Ethyl Acetate Fraction from Alchornea glandulosa
}

\author{
Flávia Cristine Mascia Lopes, ${ }^{a}$ Tamara Regina Calvo, ${ }^{b}$ Wagner Vilegas, ${ }^{b}$ and \\ Iracilda Zeppone CARLOS*,a \\ ${ }^{a}$ Departamento de Análises Clínicas, Faculdade de Ciências Farmacêuticas, UNESP-Universidade Estadual Paulista; \\ Rua Expedicionários do Brasil 1601, CEP 14801-902, Araraquara, São Paulo, Brazil: and ${ }^{b}$ Departamento de Química \\ Orgânica, Instituto de Química, UNESP; Rua Francisco Degni, S/N, CEP 14800-900, Araraquara, São Paulo, Brazil. \\ Received November 13, 2004; accepted May 27, 2005
}

The effects of Alchornea glandulosa ethyl acetate fraction (AGF) on hydrogen peroxide $\left(\mathrm{H}_{2} \mathrm{O}_{2}\right)$, nitric oxide (NO) and tumor necrosis factor- $\alpha($ TNF- $\alpha$ ) production in peritoneal macrophages activated with lipopolysaccharide (LPS) or phorbol myristate acetate (PMA) were investigated. Analysis by thin layer chromatography (TLC) of AGF showed several constituents, including flavonoids, which may have anti-inflammatory activity. Inhibitory effects of the fraction in $\mathrm{H}_{2} \mathrm{O}_{2}$ and $\mathrm{NO}$ production ranged from $8.59 \pm 7.84 \%$ to $70.56 \pm 4.16 \%$ and from $16.06 \pm 3.65 \%$ to $38.73 \pm 3.90 \%$, respectively. The TNF- $\alpha$ production was only partially inhibited in the tested concentrations $(12.21 \pm 6.23 \%-15.16 \pm 0.96 \%)$. According to these results, it is suggested that AGF has anti-inflammatory activity. This medicinal plant may have therapeutic potential in the control of inflammatory disorders.

Key words Alchornea glandulosa; anti-inflammatory activity; flavonoid; hydrogen peroxide; nitric oxide; TNF- $\alpha$

From a historical perspective, medicines production and the pharmacological treatment of diseases started with the use of medicinal plants. ${ }^{1)}$ Reports showed that about $80 \%$ of the world population uses plants for medical purposes. ${ }^{2)}$ Despite all of the powerful analytical techniques available, the majority of plant species has not been investigated chemical or biologically in any great detail and even well know medicinal plants require further clinical studies. ${ }^{3)}$

In order to adapt to environmental insults, plants produce many natural products that have antimicrobial and immunomodulating potential. ${ }^{4)}$ Alchornea glandulosa, a tree that is about $10-20 \mathrm{~m}$ tall, is known as tapiá. In Brazilian territory, this plant is distributed from southeast to south. ${ }^{5)}$

The immune system generates an enormous variety of cells and molecules capable of specifically recognizing and eliminating an apparently limitless variety of foreign invaders. These cells and molecules act together in an exquisitely adaptable dynamic network whose complexity rivals that of the nervous system. ${ }^{6}$ The monocytes/macrophages are important cells in host defense synthesizing several mediators. The $\mathrm{H}_{2} \mathrm{O}_{2}$ has many different functions in the human body. It acts as a signaling molecule, as a cytotoxic agent in the defense system and it can also cause diseases. ${ }^{7-10)} \mathrm{H}_{2} \mathrm{O}_{2}$ is formed by a coordinated sequence of biochemical reactions that is initiated by an increase in oxygen uptake followed by the one-electron reduction of oxygen $\left(\mathrm{O}_{2}\right)$ to superoxide anion $\left(\mathrm{O}_{2}^{-}\right)$, in reaction catalyzed by an NADPH oxidase. $\mathrm{O}_{2}^{-}$is subsequently converted to $\mathrm{H}_{2} \mathrm{O}_{2} \cdot{ }^{11,12)}$

The NO is another molecule that has numerous and complex biological activities. It is generated by nitric oxide synthases (NOS), a group of evolutionarily conserved cytosolic or membrane bound isoenzymes that convert the amino acid L-arginine to citrulline and NO. Neuronal NOS (nNOS), inducible NOS (iNOS) and endothelial NOS (eNOS) differ with respect to the main mode of regulation, their key functions, the average amount of NO produced and the tissue ex- pression pattern in vivo. ${ }^{13)}$

With increasing information about the regulation of immune reactions, it becomes apparent that these responses are controlled, in part, by soluble cytokines produced by macrophages. Cytokines are low-molecular-weight regulatory proteins or glycoproteins secreted by white blood cells and various other cells in the body in response to a number of stimuli. These proteins assist in regulation the development of immune effectors cells, and some cytokines possess direct effector functions of their own. They serve as messengers of the immune system. ${ }^{6}$ ) Among the cytokines, tumor necrosis factor- $\alpha$ (TNF- $\alpha$ ) exerts a key role in the cytokine network with regard to the pathogenesis of many infectious and inflammatory diseases. ${ }^{14)}$

The objective of this study was to investigate the immunomodulatory activities of $\mathrm{AGF}$ in the murine immune system by determination of oxygen $\left(\mathrm{H}_{2} \mathrm{O}_{2}\right)$ and nitrogen (NO) intermediate reactive and TNF- $\alpha$.

\section{MATERIAL AND METHODS}

Plant Material Leaves of A. glandulosa were collected at Parque Florestal ESALQ-USP, Piracicaba, São Paulo state, Brazil (June 2003). They were identified by Prof. Dr. Jorge Tamashiro from State University of Campinas (UNICAMP), São Paulo state, Brazil. A voucher specimen $\left(n^{\circ} 132828\right)$ was deposited at the Herbarium of UNICAMP.

Ethyl Acetate Fraction The leaves (500 g) were air dried $\left(7 \mathrm{~d}\right.$ at $\left.40^{\circ} \mathrm{C}\right)$ and powdered. The powdered dried leaves were exhaustively macerated with chloroform and methanol successively at room temperature ( 3 times, $48 \mathrm{~h}$ for each solvent). The extracts were concentrated under vacuum, yielding $21 \mathrm{~g}$ and $59 \mathrm{~g}$ of residues, respectively. The methanol extract ( $15 \mathrm{~g})$ was partitioned between ethyl acetate and water.

The AGF was dissolved in dimethyl sulfoxide (DMSO) 
and then diluted in culture medium (RPMI-1640). None of the samples had more than $0.5 \%$ of DMSO.

Phytochemical Analysis AGF was analyzed by TLC (TLC plates, silica gel on glass, $20 \mathrm{~cm} \times 20 \mathrm{~cm}$, Aldrich) using a solvent mixture composed of chloroform : methanol: $n$-propanol: water $(5: 6: 1: 4, \mathrm{v} / \mathrm{v} / \mathrm{v} / \mathrm{v})$ and compared with authentic standards available in our laboratory. The plates were spraying with specific reagents and after that were observed under UV light: Dragendorff's reagent and iodoplatinate (alkaloids), natural products/polyethylene glycol (NP/PEG) reagent (flavonoids), ammonia vapors (phenolic compounds), anisaldehyde-sulphuric acid reagent (saponins and triterpenes), 5\% ferric chloride solution in methanol and with $1 \%$ gelatin solution and iodine vapours (tannins). ${ }^{15)}$

Animals Swiss mice (6-8 weeks old, weighing 18 to $25 \mathrm{~g}$ ), supplied by animal house of the Faculty of Pharmaceutical Science of Araraquara were maintained in a polycarbonate box (at $23 \pm 1{ }^{\circ} \mathrm{C}, 55 \pm 5 \%$ humidity, $10-18$ circulations/h and a 12-h light/dark cycle), with water and food available ad libitum.

Peritoneal Macrophages Thioglycollate-elicited peritoneal exsudate cells (PEC) were harvested from Swiss mice using $5.0 \mathrm{ml}$ of sterile PBS, $\mathrm{pH} 7.4$. The cells were washed twice by centrifugation at $200 \mathrm{~g}$ for $5 \mathrm{~min}$ at $4{ }^{\circ} \mathrm{C}$ and resuspended in appropriate medium for each test.

Cell Viability For the determination of the cell viability, PEC $\left(2 \times 10^{6}\right)$ was utilized. The adherent cells were incubated for $1 \mathrm{~h}$ with AGF and PMA $(0.2 \mu \mathrm{M})$. PEC $\left(5 \times 10^{6}\right)$ was also utilized and the adherent cells were incubated with the fraction and LPS $(1 \mu \mathrm{g} / \mathrm{ml})$ for $24 \mathrm{~h}$. After incubation, the medium was poured off, and macrophages were incubated with MTT $(1 \mathrm{mg} / \mathrm{ml})$ for $3 \mathrm{~h}$. The formazan formed was dissolved in acidic 2-propanol and the optical density was measured using a microplate reader (Multiskan, Labsystem) equipped with a 540-nm filter and $620 \mathrm{~nm}$ reference filter. The optical density of dissolved formazan in the control (untreated cells) was taken as $100 \%$ of viability. $\left.{ }^{16}\right)$

$\mathrm{H}_{2} \mathrm{O}_{2}$ Measurement PEC (adherent cells) at $2 \times$ $10^{6}$ cells $/ \mathrm{ml}$ was suspended in a solution containing $140 \mathrm{~mm}$ $\mathrm{NaCl}, 10 \mathrm{~mm}$ potassium phosphate buffer, $\mathrm{pH} 7.0,5.5 \mathrm{~mm}$ dextrose, $0.56 \mathrm{~mm}$ phenol red, and $0.01 \mathrm{mg} / \mathrm{ml}$ type II horseradish peroxidase (HRP). Next, $100 \mu \mathrm{l}$ of this suspension was added to each of the wells of a 96-well flat-bottom tissue culture plate and exposed to AGF $(50 \mu \mathrm{l})$ and PMA $0.2 \mu \mathrm{M}$ $(50 \mu \mathrm{l})$. Cells incubated just with PMA were used as a positive control. The cells were incubated for $1 \mathrm{~h}$ at $37^{\circ} \mathrm{C}$ in a $7.5 \% \mathrm{CO}_{2}$ atmosphere. The reaction was stopped with $10 \mu \mathrm{l}$ of $4 \mathrm{~N} \mathrm{NaOH}$ and the samples were read at $620 \mathrm{~nm}$ with a Multiskan Ascent ELISA reader (Labsystems) against a blank containing phenol red solution and $4 \mathrm{~N} \mathrm{NaOH}$. The results were expressed as nanomoles of $\mathrm{H}_{2} \mathrm{O}_{2} / 2 \times 10^{5}$ cells, from a standard curve established in each test consisting of known molar concentrations of $\mathrm{H}_{2} \mathrm{O}_{2}$ in buffered phenol red. ${ }^{11,12)}$

Measurement of NO Production NO production was determined by assaying culture supernatants for nitrite using Griess reagent. PEC (adherent cells) at $5 \times 10^{6}$ cells $/ \mathrm{ml}$ was incubated with AGF and LPS $(1 \mu \mathrm{g} / \mathrm{ml})$ for $24 \mathrm{~h}$ at $37^{\circ} \mathrm{C}$ in a $7.5 \% \mathrm{CO}_{2}$ atmosphere. Cell-free supernatant $(100 \mu \mathrm{l})$ was mixed with $100 \mu \mathrm{l}$ of Griess reagent (sulfanilamide $0.1 \%$, phosphoric acid 3\%, naphthylethylenediamine $0.1 \%$ ) and incubated at room temperature for $10 \mathrm{~min}$. Cells incubated with LPS were used as a positive control. After incubation, the absorbance of the wells was determined by using a microplate reader (Multiskan, Labsystem) equipped with a 540-nm filter. Nitrite concentration was determined using dilutions of sodium nitrite in culture medium as standards. ${ }^{17)}$

Measurement of TNF- $\alpha$ Production For the cytokine immunoassay, PEC (adherent cells) at $5 \times 10^{6} / \mathrm{ml}$ was incubated for $24 \mathrm{~h}$ with AGF and LPS $(1 \mu \mathrm{g} / \mathrm{ml})$ at $37^{\circ} \mathrm{C}$ in a $7.5 \% \quad \mathrm{CO}_{2}$ atmosphere. Supernatants were removed and TNF- $\alpha$ production was quantified by a sandwich immunoassay kit (BD Biosciences Pharmingen) following the manufacturer's instructions.

Statistical Analysis The results are expressed as means \pm S.D. Each experiment was performed at least five times. One-way ANOVA with Dunnett's post test was performed using GraphPad InStat version 3.00 for Windows 95, GraphPad Software, San Diego, California, U.S.A. Values of $p<$ 0.05 were considered statistically significant.

\section{RESULTS AND DISCUSSION}

Many plants utilized in traditional medicine modulate the immune response ${ }^{18)}$ and the active compounds of these plants were isolated and studied. ${ }^{19,20)}$ Plants from tropical rainforests represent a rich source of potential immunomodulating substances. ${ }^{21)}$ Genus Alchornea species are present in South and southeast Atlantic Forest and also in Amazon Rain Forest in Brazil. 22,23$)$

AGF analysis by TLC indicated the presence of several constituents like gallic acid derivatives, glycoside flavonoids, tannins and alkaloids, but the majority of the compounds were flavonoids (Table 1). Although a great amount of flavonoids were found in the fraction and they have long been recognized to possess many different activities, ${ }^{24)}$ further experiments are necessary to verify what class of compound is responsible for the results found in this research.

Gallic acid, ethyl gallate and the flavonoids quercetin-3$O-\alpha$-L-rhamnoside, kaempferol-3-O- $\alpha$-L-rhamnoside and myricetin-3-O- $\alpha$-L-rhamnoside were found in $A$. glandulosa. ${ }^{25)}$ A mixture of steroids (sitosterol and stigmasterol), terpenoid loliolide, guanidine alkaloid $N-1, N-2, N-3$-triisopentenylguanidine and tannin corilagin were also reported. ${ }^{26)}$

Flavonoids have different chemical structures and characteristics. They have been reported to exhibit a wide range of biological effects, including antibacterial, antiviral, anti-in-

Table 1. Major Constituents of AGF

\begin{tabular}{ll}
\hline \hline Classes of compounds & AGF \\
\hline Gallic acid derivatives & $\mathrm{X}$ \\
Glycoside flavonoids & $\mathrm{X}$ \\
Phenolic acids & $\mathrm{X}$ \\
Alkaloids & $\mathrm{X}$ \\
Tannins & $\mathrm{X}$ \\
Saccharides & - \\
Lipids & - \\
Proteins & - \\
\hline
\end{tabular}

The symbol (X) indicates the presence and (-) the absence of the classes of compound. 
flammatory and antiallergic. In addition they inhibit lipid peroxidation and the activity of enzyme systems including cyclo-oxygenase and lipoxygenase. ${ }^{27)}$ These compounds are known to have antioxidant and anti-inflammatory activity. ${ }^{24)}$

Once a cell is explanted from its normal environment, the question of viability, particularly in the course of experimental manipulations, becomes fundamental. ${ }^{28)}$ The cytotoxic effect of only AGF was evaluated using the MTT assay (Fig. 1). Under the experimental conditions described above, small cytotoxic effects were observed during the concentration range studied by MTT assay, allowing the development of all experiments.

The cytotoxic effect of AGF was also evaluated in the presence of LPS or PMA (Fig. 2). Viability levels higher than $86.5 \%$ were observed in all different concentrations of the fraction incubated with PMA. The viability percentage of the different fraction concentrations incubated with LPS ranged from 76.82 to $97.97 \%$.

Severe oxidative stress is associated with threats to cell function and viability, resulting in activation of repair mechanisms or apoptosis and sometimes necrosis. ${ }^{9)}$ In this study, AGF could strongly inhibit $\mathrm{H}_{2} \mathrm{O}_{2}$ production in macrophages stimulated by PMA. The inhibition percentage ranged from 8.59 to $70.56 \%$ (Fig. 3, Table 2). Experiments using lower concentrations showed small inhibitory values, but from the concentration 15.62 to $62.50 \mu \mathrm{g} / \mathrm{ml}$, the inhibitory rate was similar, approximately $70 \%$. It's an interesting result since long exposures to high concentrations of $\mathrm{H}_{2} \mathrm{O}_{2}$ can destroy biological structures and lead to irreversible cell damage. ${ }^{29)}$

Procyanidins from Vitis vinifera are compounds from grape seeds used for protection against oxidative stress induced by free radicals and active oxygen species. They inhibited the PMA-induced release of $\mathrm{H}_{2} \mathrm{O}_{2}$ by polimorphonuclears. $^{30)}$

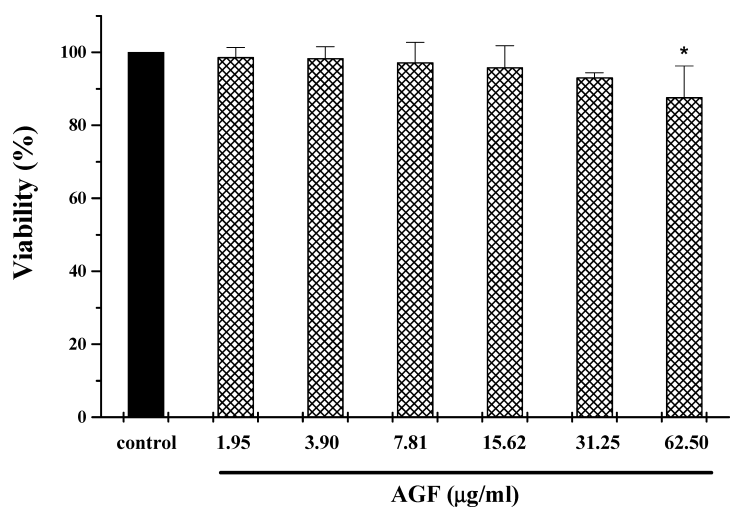

Fig. 1. AGF Effects on the Viability of Peritoneal Macrophages

Adherent cells $\left(5 \times 10^{6}\right)$ were incubated with AGF for $24 \mathrm{~h}$. Cells in culture medium (control) correspond to $100 \%$ of viability. The cell viability was determined by MTT assay as described previously. One-way ANOVA with Dunnett's post test was performed. $* p<0.01 v s$. control.
AGF could also inhibit NO and TNF- $\alpha$ production. NO production was inhibited in a dose-dependent manner and the values showed that TNF- $\alpha$ production had a mild inhibition. The NO inhibition percentage ranged from 16.06 to $38.73 \%$ (Fig. 4, Table 2) and TNF- $\alpha$ inhibition percentage was $12.21 \%$ and $15.16 \%$ (Fig. 5, Table 2).

Nitric oxide (NO) and reactive oxygen species affect virtually every step of the development of inflammation. Large

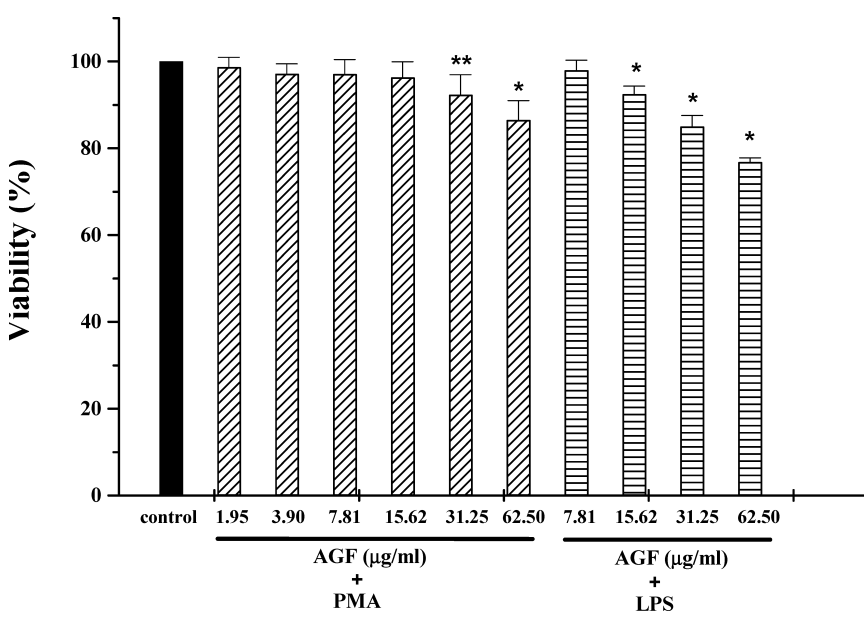

Fig. 2. AGF Effects on the Viability of Peritoneal Macrophages in the Presence of PMA or LPS

For the test using PMA, adherent cells $\left(2 \times 10^{6}\right)$ were incubated for $1 \mathrm{~h}$ with AGF and PMA $(0.2 \mu \mathrm{M})$. Adherent cells $\left(5 \times 10^{6}\right)$ were also incubated with AGF and LPS $(1 \mu \mathrm{g} / \mathrm{ml}$ ) for $24 \mathrm{~h}$. Cells in culture medium (control) correspond to $100 \%$ of viability. The cell viability was determined by MTT assay as described previously. One-way ANOVA with Dunnett's post test was performed. $* p<0.01 v s$. control. $* * p<0.05$ vs. control.

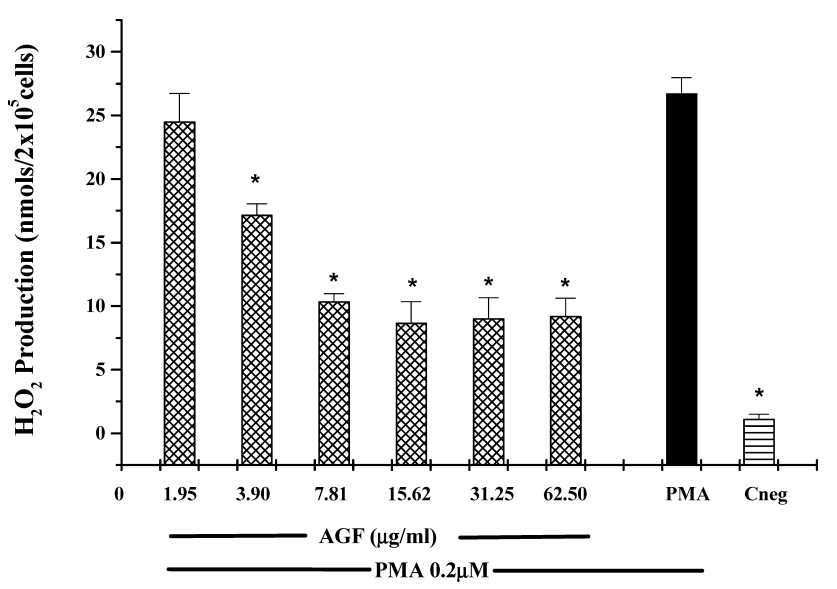

Fig. 3. AGF Effects on $\mathrm{H}_{2} \mathrm{O}_{2}$ Synthesis in Peritoneal Macrophages

Adherent cells $\left(2 \times 10^{6}\right)$ were suspended in a phenol red solution containing horseradish peroxidase and exposed to AGF and PMA $(0.2 \mu \mathrm{M})$. Cells incubated just with PMA were used as a positive control and cells in potassium phosphate buffer as a negative control. One-way ANOVA with Dunnett's post test was performed. $* p<0.01 v s$. PMA control.

Table 2. AGF Inhibitory Effects on $\mathrm{H}_{2} \mathrm{O}_{2}, \mathrm{NO}$ and TNF- $\alpha$ Production

\begin{tabular}{|c|c|c|c|c|c|c|}
\hline \multicolumn{7}{|c|}{ Inhibition (\%) } \\
\hline & $1.95 \mu \mathrm{g} / \mathrm{ml}$ & $3.90 \mu \mathrm{g} / \mathrm{ml}$ & $7.81 \mu \mathrm{g} / \mathrm{ml}$ & $15.62 \mu \mathrm{g} / \mathrm{ml}$ & $31.25 \mu \mathrm{g} / \mathrm{ml}$ & $62.50 \mu \mathrm{g} / \mathrm{ml}$ \\
\hline $\mathrm{H}_{2} \mathrm{O}_{2}$ production & $8.59 \pm 7.84$ & $37.15 \pm 6.23$ & $63.83 \pm 4.86$ & $70.56 \pm 4.16$ & $69.03 \pm 7.29$ & $68.38 \pm 5.89$ \\
\hline NO production & - & - & $16.06 \pm 3.65$ & $21.67 \pm 6.43$ & $30.67 \pm 8.02$ & $38.73 \pm 3.90$ \\
\hline TNF- $\alpha$ production & - & - & - & $12.21 \pm 6.23$ & - & $15.16 \pm 0.96$ \\
\hline
\end{tabular}




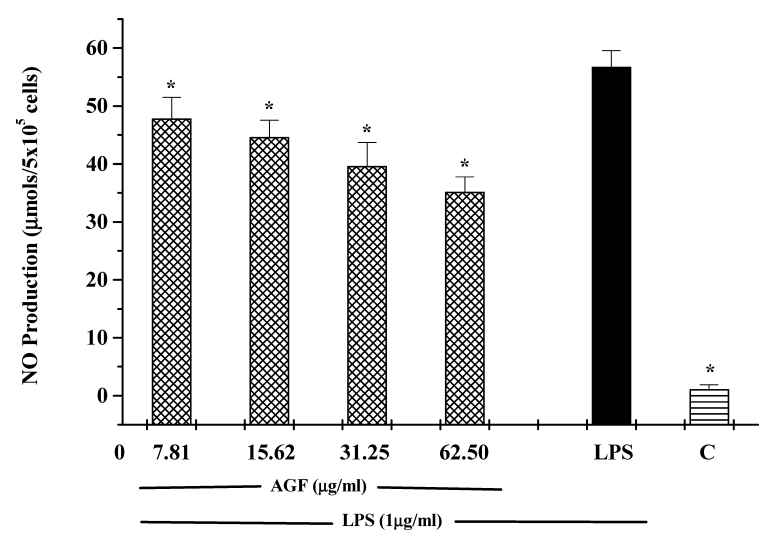

Fig. 4. AGF Effects on NO Synthesis in Peritoneal Macrophages

Adherent cells $\left(5 \times 10^{6}\right)$ were incubated for $24 \mathrm{~h}$ with AGF and LPS $(1 \mu \mathrm{g} / \mathrm{ml})$. Cellfree supernatant was mixed with Griess reagent. Cells incubated just with LPS were used as a positive control and cell in culture medium (RPMI-1640) as a negative control. One-way ANOVA with Dunnett's post test was performed. $* p<0.01 v s$. LPS control.

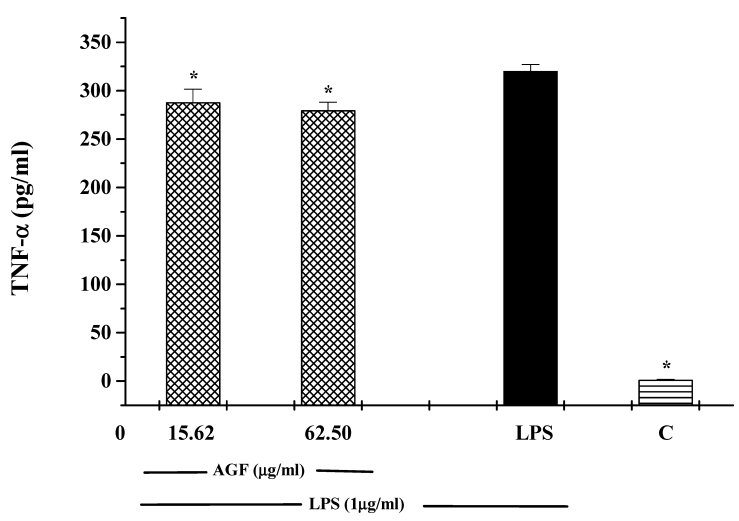

Fig. 5. AGF Effects on TNF- $\alpha$ Synthesis in Peritoneal Macrophages

For the cytokine immunoassay, adherent cells $\left(5 \times 10^{6} / \mathrm{ml}\right)$ were incubated for $24 \mathrm{~h}$ with AGF and LPS $(1 \mu \mathrm{g} / \mathrm{ml})$. Cells incubated just with LPS were used as a positive control and cell in culture medium (RPMI-1640) as a negative control. One-way ANOVA with Dunnett's post test was performed. $* p<0.01 v s$. LPS control.

amounts of NO, generated primarily by iNOS can be toxic and pro-inflammatory. Similarly $\mathrm{O}_{2}^{-}$produced by NADPH oxidases may lead to toxic effects, when produced at high levels during oxidative burst. ${ }^{31)}$ Nitric oxide is not a strong oxidant; however, nitric oxide reacts at a nearly diffusionlimited rate with superoxide to form a strong oxidant, peroxynitrite. Peroxynitrite is formed by activated inflammatory cells and agonist-stimulated endothelial cells, and has been found to oxidize several biological molecules and to nitrate free or protein tyrosine residues and other phenolics. ${ }^{32,33)}$

When iNOS is synthetized, it releases higher NO quantities than cNOS and the production of NO continue until Larginine or the cofactors are depleted or when cellular death occurs. ${ }^{34)}$ Prolonged exposure to a large amount of NO, as in activation of iNOS, inhibits the activity of several enzymes, such as aconitase, cytochrome $c$ oxidase and ribonucleotide reductase. Thus, NO may becomes cytotoxic or cytostatic. ${ }^{35)}$

Agents that modulate the activity of NO may be of considerable therapeutic value. In particular, those that reduce the formation of NO may be beneficial in pathophysiological conditions where excessive production of NO is a contributory factor. These include diseases such as septic shock, neurodegenerative disorders, and inflammation. ${ }^{36)}$
Some pro-inflammatory cytokines, notably interleukin-1, interleukin-6, tumor necrosis factor- $\alpha$, and interferon- $\gamma$, and the bacterial lipopolysaccharide (LPS), are potent agents stimulating the induction of inducible nitric oxide in the macrophages (iNOS). ${ }^{37)}$ TNF- $\alpha$ induces a number of pro-inflammatory changes in endothelial cells, including cytokine production, expression of adhesion molecules, releasing procoagulatory substances and induction of iNOS. These alterations may lead to septic shock. ${ }^{14)}$ In particular, enhanced tumour-necrosis factor- $\alpha$ (TNF- $\alpha$ ) synthesis is associated with the development of rheumatoid arthritis, psoriatic arthritis and inflammatory bowel disease. ${ }^{38)}$

Resveratrol, occurring flavonoid in grapes, powerful inhibited NO generation in activated macrophages and also reduced the amount of cytosolic iNOS protein. ${ }^{39)}$ Flavonoids isolated from citrus were evaluated for their ability to affect the inflammation response through suppression of cytokine expression by human monocytes. Several polymethoxylated flavones inhibited lipopolysaccharide-induced monocyte expression of TNF- $\alpha{ }^{40}$ ) Different classes of flavonoids are known to scavenge oxygen free radicals. ${ }^{41)}$

Other species of Alchornea genus showed biological effects. A. castaneifolia exhibited inhibitory activity of ethyl phenilpropiolate induced rat ear oedema in vivo and moderate inhibition of COX-1 catalyzed prostaglandin biosynthesis in vitro. ${ }^{42}$ Alchornea cordifolia inhibited HIV-1 strain $\mathrm{HTLVIII}_{\mathrm{B}}$ cytopathicity and the seeds had high antiviral indices. ${ }^{43)}$ A-ring-opened triterpenoids form A. latifolia showed in vitro cytotoxic activity against Hep-G2 and A-431 human cancer cell lines and inhibit topoisomerase II. ${ }^{44)}$

Previous experiments realized in our lab have showed that AGF does not have any effect inhibiting HRP. The results of the present study indicate that $\mathrm{H}_{2} \mathrm{O}_{2}$ inhibition was probably due the potential of $A$. glandulosa to scavenge $\mathrm{H}_{2} \mathrm{O}_{2}$, since $A$. glandulosa has strong antioxidant activity (paper in preparation). Possibly, AGF can also inhibit the induction of iNOS in LPS-activated murine macrophages at the transcriptional level, because LPS-induced NO production was inhibited by AGF in a concentration-dependent manner. Now, it is important to verify if $\mathrm{NF}-\kappa \mathrm{B}$ activation can be inhibit by AGF, whereas NF- $\kappa \mathrm{B}$ is one of the most important transcription factors in the control of pro-inflammatory genes as TNF- $\alpha$ and iNOS. Besides, TNF- $\alpha$ secretion by macrophages in response to LPS stimulation is not only regulated by mRNA inducible but also by mRNA stability ${ }^{45}$ and proteolytic processing. ${ }^{46)}$ Thus, it is possible that AGF affects some of those processes. Experiments are in progress to elucidate these mechanisms, but our findings prove the real potential of this plant.

Immunomodulation using medicinal plants can provide an alternative to conventional chemotherapy for a variety of diseases, especially when host defense mechanism has to be activated under the conditions of impaired immune response or when a selective immunossupressor is desired in situations like autoimmune disorders. ${ }^{47)}$

According to this work, it is possible to suggest that ethyl acetate fraction obtained from A. glandulosa presents anti-inflammatory activity. Our findings may contribute to a better understanding of the beneficial effects of this medicinal plant. 
Acknowledgements We thank Fundação de Amparo à Pesquisa do Estado de São Paulo (FAPESP) for fundings from Biota-Fapesp Program, CAPES for the grant and Marisa Campos Polesi Placeres, the technician of the Laboratório de Imunologia Clínica.

\section{REFERENCES}

1) Schulz V., Hänsel R., Tyler V. E., "Fitoterapia Racional: um guia de fitoterapia para as ciências da saúde," Manole, Barueri, 2002.

2) Fetrow C. W., Avila J. R., "Manual de medicina alternativa para o Professional," Guanabara Koogan, Rio de Janeiro, 2000.

3) Phillipson J. D., Planta Med., 69, 491-495 (2003).

4) Dixon R. A., Nature (London), 411, 843-847 (2001).

5) Lorenzi H., "Árvores Brasileiras: manual de identificação e cultivo de plantas e árvores nativas do Brasil," Plantarum, Nova Odessa, 1992.

6) Goldsby R. A., Kindt T. J., Osborne B. A. W. H., "Kuby Immunology," 4th ed., W. H. Freeman and Company, New York, 2000.

7) Abe J., Bradford B. C., J. Biol. Chem., 274, 21003-21010 (1999).

8) Clement M., Ponton A., Pervaiz S., FEBS Lett., 440, 13-18 (1998).

9) Forman H. J., Torres M., Am. J. Respir. Crit. Care Med., 166, S4-S8 (2002).

10) Halliwell B., Clement M. V., Long L. H., FEBS Lett., 486, 10-13 (2000).

11) Pick E., Keisari Y., J. Immunol. Methods, 38, 161-170 (1980).

12) Pick E., Mizel D. J., J. Immunol. Methods, 46, 211-226 (1981).

13) Bogdan C., Trends Cell Biol., 11, 66-75 (2001).

14) Eigler A., Sinha B., Hartmann G., Endres S., Immunol. Today, 18, 487-492 (1997)

15) Wagner H. M., Bladt S., Zgainski E. M., "Plant Drug Analysis," Springer, Berlin, 1986.

16) Mosmann T., J. Immunol. Methods, 65, 55-63 (1983).

17) Green L. C., Wagner D. A., Glogowski J., Skipper P. L., Wishnok J. S., Tannenbaum S. R., Analytic. Biochem., 126, 131-138 (1982).

18) Agarwal S. S., Singh V. K., Proc. Indian Natl. Sci. Acad. B, 65, 179204 (1999).

19) Graham J. G., Quinn M. L., Fabricant D. S., Fransworth N. R., J. Ethnopharmacol., 73, 347-377 (2000).

20) Yamaguchi H., Adv. Exp. Med. Biol., 319, 287-297 (1992).

21) Williams J. E., Altern. Med. Rev., 6, 567-579 (2001).

22) Tabarelli M., Mantovani W., Rev. Bras. Biol., 59, 239-251 (1999).

23) Taylor L., "Herbal Secrets of the Rainforest," 2nd ed., Prima Publishing, Rocklin, 1998.
24) Middleton E., Jr., Kandaswami C., Theoharide T. C., Pharmacol. Rev, 52, 673-751 (2000).

25) Urrea-Bulla A., Suárez M., Moreno-Murillo M. B., Fitoterapia, 75, 392-394 (2004).

26) Conegero L. S., Ide R. M., Nazari A. S., Sarragiotto M. H., Filho B. P. D., Nakamura C. V., Carvalho J. E., Foglio M. A., Quim. Nova, 26, $825-827$ (2003).

27) Cook C. N., Samman S., J. Nutr. Biochem., 7, 66-76 (1996).

28) Freshney R. I., "Culture of Animal Cells: A Manual of Basic Technique," 3rd ed., Wily-Liss, New York, 1994.

29) Ramasarma T., Indian J. Biochem. Biophys., 27, 269-274 (1990).

30) Lu Y., Zhao W. Z., Chang Z., Chen W. X., Li L., Acta Pharmacol. Sin., 25, 1083-1089 (2004)

31) Guzik T. J., Korbut R., Adamek-Guzik T., J. Physiol. Pharmacol., 54, $469-487$ (2003).

32) Ischiropoulos H., Nelson J., Duran D., Al-Medhdi A., Free Rad. Biol. Med., 20, 373-381 (1996).

33) Linares E., Giorgio S., Mortara R. A., Santos C. X. C., Yamada A. T., Augusto O., Free Rad. Biol. Med., 30,1234-1242 (2001).

34) Dusting G. J., Macdonald P. S., Ann. Med., 27, 395-406 (1995).

35) Achike F. I., Kwan C. Y., Clin. Exp. Pharmacol. Physiol., 30, 605615 (2003).

36) Hobbs A. J., Higgs A., Moncada S., Annu. Rev. Pharmacol. Toxicol., 39, 191-220 (1999).

37) Chu S. C., Wu H. P., Banks T. C., Eissa N. T., Moss J., J. Biol. Chem., 270, 10625-10630 (1995).

38) Palladino M. A., Bahjat F. R., Theodorakis E. A., Moldawer L. L., Nat. Rev. Drug Discov., 2, 736-746 (2003).

39) Tsai S. H., Lin-Shiau S. Y., Lin J. K., Br. J. Pharmacol., 126, 673680 (1999).

40) Manthey J. A., Grohmann K., Montanari A., Ash K., Manthey C. L., J. Nat. Prod., 62, $441-444$ (1999).

41) Bors W., Saran M., Free Radic. Res. Commun., 2, 289-294 (1987).

42) Dunstan C. A., Noreen Y., Serrano G., Cox P. A., Perera P., Bohlin L., J. Ethnopharmacol., 57, 35-56 (1997).

43) Ayisi N. K., Nyadedzor C., Antiviral Res., 58, 25-33 (2003).

44) Setzer W. N., Shen X., Bates R. B., Burns J. R., Mcclure K. J., Zhan P., Moriarity D. M., Lawton R. O., Fitoterapia, 71, 195-198 (2000).

45) Clark A., Arthritis Res., 2, 172-174 (2000).

46) Moss M. L., White J. M., Lambert M. H., Andrews R. C., Drug Discov. Today, 6, 417-426 (2001).

47) Ganju L., Karan D., Chanda S., Srivastava K. K., Sawhney R. C., Selvamurthy W., Biomed. Pharmacother., 57, 296-300 (2003). 